\title{
A Temporal Model of Perceived Control to Explain Service Failures
}

\author{
Natalia Araujo Pacheco ${ }^{1,2}$ \\ Cristiane Pizzutti ${ }^{3}$ \\ Maggie Geuens ${ }^{4}$ \\ IPAM, Lisboa, Portugal ${ }^{1}$ \\ Faculdade Meridional, Passo Fundo, RS, Brazil ${ }^{2}$ \\ Universidade Federal do Rio Grande do Sul, Porto Alegre, RS, Brazil ${ }^{3}$ \\ Universiteit Gent, Gent, Belgium $^{4}$
}

Received 19 July 2018. This paper was with the authors for one revision. Accepted 28 April 2019. First published online 30 May 2019.

Thomas Brashear Alejandro was the associate editor for this article.

Editorial assistant: Luciane Kato Kiwara

Editor-in-chief: Carlo Gabriel Porto Bellini 


\begin{abstract}
Research on service failure has neglected the temporal dimension of consumer-perceived control (i.e., past, present and future control). This paper introduces the temporal model of perceived control to service research and compares its explanatory power for consumers' emotional and behavioural reactions after a service failure to that of the causal attribution model. The results of a correlational study show that the temporal model of perceived control has greater explanatory power than the causal attribution model (i.e., the former can better predict consumers' regret, self-focused anger, and repurchase behaviour after a stressful service episode). This is the first empirical research to use a temporal model of perceived control to explain consumer reactions after service failures, showing that this model may be combined with others in a complementary way to provide a better understanding of consumer reactions.
\end{abstract}

Keywords: perceived control; causal attribution; service failure; dissatisfaction; service recovery. 


\section{Introduction}

Service failures are realities in the service industry, and by no means can their occurrence be fully prevented (Joireman, Grégoire, Devezer, \& Tripp, 2013). Some of these failures lead consumers to get angry with their service providers, ruminate about the failures and seek revenge (Grégoire, Laufer, \& Tripp, 2010; Strizhakova, Tsarenko, \& Ruth, 2012); at the same time, failures cause consumers to think about their own role in the situation. Consider the following complaint about a hospital laboratory, posted on ConsumerAffairs.com:

I have had blood work done annually. Every year. Same insurance. No problems. Today I was asked for my driver's license and a credit card was demanded!! This NEVER happened before. Does this sound like the start of identity theft? I was very upset and should have left, but I handed over the documentation like a fool. Now I will be worried for months. I am planning to cancel my credit card. Will use another lab (P., 2017).

This complaint shows that although the consumer thinks that the employee was wrong in requiring her personal documents - which denotes external attribution according to the attribution model (Weiner, 1985) - she regrets providing the documents, which she could have controlled in the past (i.e., during the service encounter). The consumer's comment that she will be worried for months suggests her lack of control over her present thoughts about what happened. When she mentions her plan to cancel her credit card and switch to another laboratory, it implies her control over the situation in the future by avoiding further consequences and preventing the recurrence of the incident. Importantly, most of the highlighted aspects in her comment are not considered in the current models adopted in the service literature.

Current models that are used to explain consumers' emotional and behavioural reactions after product and service failures, such as the widely used causal attribution model (e.g., Dunn \& Dahl, 2012; Harris, Mohr, \& Bernhardt, 2006; Iglesias, 2009), encompass a broad range of investigations. However, such models do not address the temporal dimension of control (i.e., consumers' perceptions about their past, present and future control over service failures), which appears in the cited complaint. Recently introduced in psychology, the temporal model of perceived control (Frazier, Anders, et al., 2012; Frazier, Keenan, et al., 2011) may fill this gap. According to the authors, people's perceptions that: (a) they could have done something to prevent a stressful event (past control); (b) they can control their own emotions and thoughts about it right now (present control); (c) they can prevent its recurrence (future control); and (d) such a situation is (un)likely to recur (future likelihood) are important determinants of distress. Therefore, this temporal model of perceived control refers to cognitions that have not been addressed by the attribution model - particularly those associated with past and future times and are important to gain a better understanding of consumer reactions to service failures.

Addressing the temporal dimension of consumer-perceived control is important because perceived control has already been proven to influence consumers' emotional and behavioural reactions (Hui \& Bateson, 1991; Kumar \& Anand, 2015; Rompay, Galetzka, \& Pruyn, 2008). Moreover, depending on whether this perceived control refers to the past, present or future,

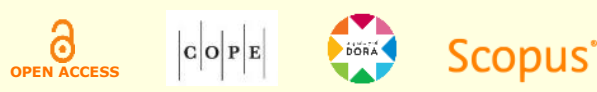


different emotional and behavioural reactions arise (Frazier, Anders, et al., 2012; Frazier, Keenan, et al., 2011). These effects of past, present and future control are yet unexplored in the context of service failures. This paper aims to highlight the potential contribution of the temporal model of perceived control to the service literature by comparing its explanatory power, considering emotional (i.e., anger and regret) and behavioural reactions (i.e., repurchase behaviour) after failures, with that of the attribution model. By understanding the effects of the temporal dimension of consumer perceived control, service providers gain important insights to prevent some consumer reactions after service failures and better manage the service provider-consumer relationship, because it is possible to influence consumer perceived control through information, choice, co-production, etc. (Chan, Yim, \& Lam, 2010; Pacheco, Lunardo, \& Santos, 2013; Skinner, 1996).

\section{Theoretical Framework}

\section{Perceived control}

Perceived control - someone's belief about how much control one has (Skinner, 1996) - has received ample research attention over the past decades. In consumer behaviour and service literature, perceived control is deemed to lead to positive effects, such as great pleasure, satisfaction and intention to do business with an organisation (Bolkan, Goodboy, \& Daly, 2010; Chang, 2008; Hui \& Bateson, 1991; Namasivayam \& Guchait, 2013; Rompay et al., 2008).

Many studies in consumer behaviour and service literature measure perceptions of control over a situation that has already occurred or is presented in the form of a scenario. For instance, some authors describe or simulate a purchase or a service situation and measure participants' perceived control over it (e.g., Bolkan et al., 2010; Chang, 2008; Dabholkar \& Sheng, 2009; Dellaert \& Dabholkar, 2009; Hui \& Bateson, 1991; Li, Xu, \& Xu, 2018; Pacheco et al., 2013; Rompay et al., 2008). Other authors ask participants to recall a situation that happened to them and report their perceived control over it (e.g., Hui \& Toffoli, 2002). Table 1 summarises the way in which empirical studies have been measuring consumer-perceived control. Table 1 evinces what has been neglected by these studies (i.e., the complete temporal dimension of perceived control - past, present, and future), while the discussion that follows this table explains why and how it can be addressed from now on. 
Table 1

Main measures of empirical studies about consumer-perceived control

\begin{tabular}{ll}
\hline Article & Measures or manipulations of perceived control \\
\hline $\begin{array}{l}\text { Hui and Bateson } \\
\text { (1991) }\end{array}$ & $\begin{array}{l}\text { Undisclosed items, some of them based on the dominance and the helplessness scales } \\
\text { (e.g., influenced/influential). }\end{array}$ \\
\hline $\begin{array}{l}\text { Hui and Toffoli } \\
\text { (2002) }\end{array}$ & $\begin{array}{l}\text { Undisclosed } \\
\text { (e.g., influenced/influential). }\end{array}$
\end{tabular}
(e.g., influenced/influential).

Kang, Hahn, Fortin It takes little time to find the coupon I need on the Internet; Whenever I want certain

Hyun and Eom coupons, I can find them on the Internet; It is easy to search, print, and redeem coupons (2006) on the Internet; As far as the coupon I need is on the Internet, it is easy for me to find it; There are few obstacles for me to use e-coupons.

Namasivayam and

Mount (2006)

The hotel helped me feel in control.

Past $^{*}$

The efforts of this online bookstore give me a sense of control over how the problem will

Chang (2008) be resolved; This online bookstore allowed me to have input on the final solution to the problem; I had some sense of control over how this situation will be resolved.

Past and

future*

In this store, I feel in control over the situation; In this store, I can easily find what I am

Rompay, Galetzka and Pruyn (2008) looking for; In this store, I am the center of attention; In this store, the customer is in control.

Present ${ }^{*}$

I felt I was in charge of my own booking while using this Web site; This Web site allowed

Dabholkar and

Sheng (2009) me to select any flight I wanted; I felt in control throughout the booking process on this Web site.

\begin{tabular}{|c|c|c|}
\hline $\begin{array}{l}\text { Dellaert and } \\
\text { Dabholkar (2009) }\end{array}$ & $\begin{array}{l}\text { I am satisfied with the amount of control I have over the customization process provided } \\
\text { in the scenario; The customization process, portrayed in the scenario, will give me } \\
\text { control over designing my own clothes. }\end{array}$ & $\begin{array}{l}\text { Present and } \\
\text { future* }^{*}\end{array}$ \\
\hline $\begin{array}{l}\text { Lunardo and } \\
\text { Mbengue (2009) }\end{array}$ & $\begin{array}{l}\text { Being controlling (controlled); influential (influenced); in control (cared-for); important } \\
\text { (awed); dominant (submissive); autonomous (guided) in a store environment. }\end{array}$ & Past $^{*}$ \\
\hline $\begin{array}{l}\text { Bolkan, Goodboy, } \\
\text { and Daly (2010) }\end{array}$ & $\begin{array}{l}\text { How important do you think your feedback was for the company?; How seriously did the } \\
\text { company take your letter?; How much of an impact did your communication have on the } \\
\text { company?; How much of an impact did your communication have on your situation? }\end{array}$ & Past $^{*}$ \\
\hline Uhrich (2011) & $\begin{array}{l}\text { Controlled/controlling; influenced/influential; cared-for/in control; awed/important, } \\
\text { submissive/dominant; guided/autonomous. }\end{array}$ & Past $^{\star}$ \\
\hline $\begin{array}{l}\text { Noone, Wirtz and } \\
\text { Kimes (2012) }\end{array}$ & $\begin{array}{l}\text { I believe that I had the ability to influence the pace of this stage of my meal; How much } \\
\text { control did you have over the pace of this stage of your meal? }\end{array}$ & Past $^{*}$ \\
\hline $\begin{array}{l}\text { Namasivayam and } \\
\text { Guchait (2013) }\end{array}$ & $\begin{array}{l}\text { I caused the service provider to give me everything I needed for service; Whatever I } \\
\text { needed for the service was available in the service encounter; and eight other } \\
\text { undisclosed items. }\end{array}$ & Past $^{\star}$ \\
\hline $\begin{array}{l}\text { Pacheco, Lunardo } \\
\text { and Santos (2013) }\end{array}$ & $\begin{array}{l}\text { In this agency, I felt in control of the situation; In this agency, I would feel able to } \\
\text { influence the way things were; and five other undisclosed items. }\end{array}$ & $\begin{array}{l}\text { Past and } \\
\text { present }^{*}\end{array}$ \\
\hline $\begin{array}{l}\text { Kumar and Anand } \\
(2015)\end{array}$ & $\begin{array}{l}\text { I can become a green consumer; I have knowledge and ability to become a green } \\
\text { consumer; If I want to become a green consumer, it would be easy. }\end{array}$ & Present* \\
\hline $\begin{array}{l}\text { Elwalda, Lü and Ali } \\
(2016)\end{array}$ & $\begin{array}{l}\text { I feel more in control of online shopping when using online customer reviews; Through } \\
\text { online customer reviews, I have a direct influence on finding the information I need; } \\
\text { Online customer reviews enable me to obtain the necessary information. }\end{array}$ & Present* \\
\hline $\begin{array}{l}\mathrm{Li}, \mathrm{Xu} \text { and } \mathrm{Xu} \\
(2018)\end{array}$ & $\begin{array}{l}\text { I can control the self-service shopping in this online shop; and four other undisclosed } \\
\text { items. }\end{array}$ & Present ${ }^{*}$ \\
\hline
\end{tabular}

Note. * It addresses this(these) dimension(s) differently from the temporal model of perceived control by Frazier, P., Anders, S., Shallcross, S., Keenan, N., Perera, S., Howard, K., \& Hintz, S. (2012). Further development of the temporal model of control. Journal of Counseling Psychology, 59(4), 623-630. https://doi.org/10.1037/a0029702; and Frazier, P., Keenan, N., Anders, S., Perera, S., Shallcross, S., \& Hintz, S. (2011). Perceived past, present, and future control and adjustment to stressful life events. Journal of Personality and Social Psychology, 100(4), 749-765. https://doi.org/10.1037/a0022405

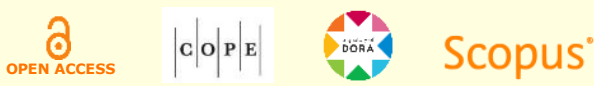


Although some of the measures shown in Table 1 use words related to past (e.g., ... I felt in control...), present (e.g., ... give me a sense of control over...) and future (e.g. ... will give me control over...), none of them investigate past, present and future control, at the same time neither investigates any of them in the same way as Frazier, Anders, et al. (2012) and Frazier, Keenan, et al. (2011) do. For instance, none of the studies addressing the past measured whether someone could have prevented an event (e.g., service failure), none of the studies addressing the present investigated perceived control over the current consequences of a purchase/service that has already happened, and none of the studies addressing the future measured perceived control over future purchases/services and the perceived ability to prevent some events in the future. In other words, the temporal dimension of perceived control (i.e., perceived control related to past, present and future) presented by Frazier, Berman, and Steward (2001) and discussed in the remainder of this section has not yet been the topic of investigation in consumer behaviour and service contexts, especially after service failures.

The temporal dimension of perceived control has been mainly investigated in the context of stressful and traumatic life events (Frazier, Berman, \& Steward, 2001; Frazier, Keenan, et al., 2011) and has been shown to have important implications for individuals' health (Wallston, Wallston, Smith, \& Dobbins, 1987). According to the temporal model of perceived control, past control refers to someone's perception that one could have prevented a stressful event, present control signifies one's perceived control over one's present reactions to a stressful event, and future control indicates one's perception that one can prevent the recurrence of a similar stressful event (Frazier, Keenan, et al., 2011). This model has a fourth component called perceived future likelihood, which refers to someone's expectation that a similar event will happen to one again (Frazier, Anders, et al., 2012). Looking at these definitions it is possible to realize that none of the measures of Table 1 refers to past, present, and future in the same way as Frazier, Anders, et al. (2012) and Frazier, Keenan, et al. (2011).

Past control is positively related to distress and negatively related to psychological well-being (Frazier, Berman, et al., 2001; Frazier, Keenan, et al., 2011; Sirois, Davis, \& Morgan, 2006), which means that individuals who think that they could have prevented a stressful event feel bad about it. In turn, present control is negatively related to distress and positively related to psychological well-being (Frazier, Berman, et al., 2001; Frazier, Keenan, et al., 2011; Sirois et al., 2006), which means that individuals who perceive that they can control their reactions to a stressful event feel better about it (i.e., they adjust better). Present control also reduces stress, depression and anxiety symptoms (Frazier, Meredith, et al., 2014). Future control consequences seem to depend on objective controllability; thinking that an event is controllable by oneself leads to negative outcomes (e.g., distress) when the event actually cannot be controlled by oneself and leads to positive outcomes (e.g., better performance) when the event can be controlled by oneself (Frazier, Keenan, et al., 2011). Finally, the effects of perceived likelihood are positively related to distress (Frazier, Anders, et al., 2012). In other words, the higher the likelihood of a stressful event's recurrence is, the higher someone's distress becomes.

It is conceivable that the temporal model of perceived control also has an impact on consumers' emotional and behavioural reactions after service failures. Regarding potential emotional

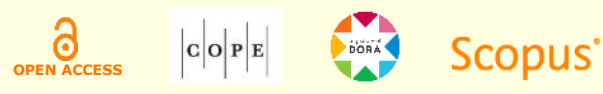


reactions, the present paper focuses on regret and anger. The choice of regret and anger from a wide range of negative emotions is due to the relevance of these emotions. Regret is the most frequently experienced negative emotion (Saffrey, Summerville, \& Roese, 2008; Shimanoff, 1984), while anger is deemed the dominant emotional reaction following service failures and a good predictor of post-purchase behaviour (Kalamas, Laroche, \& Makdessian, 2008). Concerning behavioural reactions after service failures, this paper investigates repurchase behaviour because it is usually impaired by both consumer regret and anger (Bougie, Pieters, \& Zeelenberg, 2003; Kalamas et al., 2008; Zeelenberg \& Pieters, 2004), besides its immediate impacts on the service providers' sales and revenues.

Transferring the previous findings from a psychology to a service failure context, a researcher would expect consumer-perceived past control to be positively associated with regret. Regret is a self-blame emotion derived from the comparison of a current situation to one that would have been better had the agent done something differently in the past (Zeelenberg \& Pieters, 2007). It is logical to infer that the more the consumers think that they could have prevented a service failure (high past control), the more regret they would experience. On the other hand, past control could be negatively related to anger towards the service provider. Anger is an otherfocused emotion represented by strong feelings of displeasure and hostility and a desire to attack the source of anger (Bonifield \& Cole, 2007). Anger is associated with both external and controllable attributions (Bougie et al., 2003; Folkes, 1984; Weiner, 2000). Thus, an increase in internal attributions could decrease external attributions, in line with the findings that the more the consumers perceive to have control over a service encounter, the less these consumers will be inclined to make company-focused causal attributions (Hui \& Toffoli, 2002). Therefore, the more the consumers think that they could have prevented a service failure, the less angry with the service provider they probably are.

Consumer-perceived present control could be negatively associated with regret and anger because it refers to an ability to control emotional reactions and leads to less distress and greater wellbeing (Frazier, Keenan, et al., 2011; Sirois et al., 2006). Because perceived future control is negatively related to future likelihood, while future likelihood is positively related to stress (Frazier, Anders, et al., 2012), the more the consumers perceive that they can prevent a service failure from happening again, the less likely the recurrence of such a failure will be; consequently, the less regretful and angry they feel. Despite some conjectures about the individual effects of each component of the temporal model of perceived control (i.e., past, present and future control and future likelihood) on regret and anger, this paper focuses on investigating the relevance of the temporal model of perceived control as a whole when compared with the attribution model.

\section{Comparing the temporal model of perceived control with the causal attribution model}

The attribution model refers to cognitions about who caused the failure (causal locus), whether the cause is permanent or temporary (causal stability) and whether or not the cause was controllable (causal controllability) (Weiner, 1985, 2000). Causal attributions focus on the past

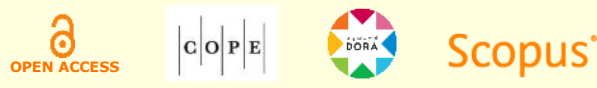


since someone makes attributions regarding something that has already happened. Attributions affect the future because interpretations of what happened in the past influence future behaviour (Folkes, 1984; Weiner, 2010). For instance, although causal stability involves an evaluation of a past event, it may affect evaluations about the future (e.g., the more stable, the more likely to recur). This probability is the focus of future likelihood, the fourth component of the temporal model of perceived control. However, the attribution model does not directly address questions about present and future times. Knowing or believing that the cause of an event is external (caused by the service provider), controllable (could have been prevented by the service provider) and temporary does not answer the question about whether this cause will be fixed by the time a consumer needs to use the same service again. In contrast, the temporal model of perceived control directly addresses questions about past, present and future times.

Consider this complaint (about a laboratory bill error) published on ConsumerAffairs.com: "I made the mistake of paying them the estimate one time, that will never happen again!” (L., 2017). This comment shows that although the company committed the error (external causal attribution), the consumer felt that she could have prevented it if she had refused to pay the bill (past control). At the same time, this consumer says she will never do it again (future control).

While the attribution model investigates causal locus, examining who was responsible for a failure, the temporal model does not question who caused the stressful event. Through its past control concept, the temporal model measures the perceived possibility of having prevented the occurrence of the stressful event. In other words, the attribution model asks, Who caused x?. The temporal model asks, Could I have prevented $\mathrm{x}$ ?. When discussing the attribution model, Weiner (2014) argues that all external causes (e.g., failures caused by the service provider) are uncontrollable by the individual. However, the literature on perceived control shows that actual control differs from perceived control (Burger, 1989; Skinner, 1996); individuals may perceive that they have control over a situation that is in fact beyond their control. In this sense, using the attribution model to discover that the service provider caused or is responsible for a failure is not enough to understand whether customers believe that they could have prevented or will be able to prevent it in the future - this preventability issue is addressed by past and future control.

Similar to past control, causal attribution of controllability also refers to preventability, but its use in a service failure context refers mainly to whether the service provider could have prevented an event (e.g., Folkes, Koletsky, \& Graham, 1987; Hess, Ganesan, \& Klein, 2003, 2007; Huang, Lin, \& Wen, 2010; Taylor, 1994; Wirtz \& Mattila, 2004). To the best of the authors' knowledge, no prior research takes the perspective of investigating whether the consumer could have prevented the service failure. The temporal model of perceived control evinces the consumer's role in the service failure by questioning whether a consumer could have prevented the service failure or would be able to do so in the future. Consequently, the temporal model brings an internal (and temporal) focus that has been neglected in service failure research over the past years. As such an internal, temporal focus has been proven to affect individuals' emotional and behavioural reactions to stressful life events (Frazier, Anders, et al., 2012; Frazier, Keenan, et al., 2011; Frazier, Meredith, et al., 2014; Misono, Meredith, Peterson, \& Frazier, 2016; Sirois et al., 2006), it could also be

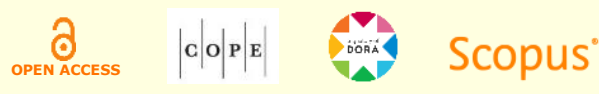


important for consumer responses to service failures. Overall, these differences make the temporal model an interesting resource to analyse service failures from a different perspective.

In sum, the temporal model of perceived control directly addresses questions about past, present, and future, as well as focuses on the consumer's perceived control over the service failure - things that the attribution model does not do. Because consumers' perceived control influences their emotional and behavioural reactions (Hui \& Bateson, 1991; Kumar \& Anand, 2015; Rompay et al., 2008), it is expected that the temporal model of perceived control could better explain some consumers' reactions after service failures when compared to the attribution model. For instance, it should better explain self-focused emotions such as regret because it addresses self-perceptions (perceived past, present, and future control) that the attribution model does not address. Similarly, the temporal model of perceived control should offer higher explanatory power than the attribution model regarding self-focused anger - although anger is usually defined as an otherfocused emotion, people sometimes report being angry with themselves (Smyth et al., 2007; Tangney et al., 1996). Thus, the following hypotheses were developed:

H1: The temporal model of perceived control will have a higher explanatory power for consumers' regret after a service failure than the attribution model.

H2: The temporal model of perceived control will have a higher explanatory power for consumers' self-focused anger after a service failure than the attribution model.

Even though hypotheses 1 and 2 predict that the temporal model of perceived control should better explain regret and self-focused anger than the attribution model, the same may not be true for other-focused emotions such as anger towards a service provider. In order to be angry towards a service provider, a consumer must believe that the service provider deliberately caused harm or was negligent (Joireman et al., 2013; Weiner, 2000), but the temporal model of perceived control does not address perceptions about other's actions and intentions. The attribution model does measure the service provider's controllability over the failure, which is closely related to judgments of responsibility (Weiner, 2014). Consequently, one may expect a better explanatory power from the attribution model, especially because it has been used to explain self-focused anger (Weiner, 1985, 2000, 2014). Thus, the following hypothesis is formulated:

H3: The temporal model of perceived control will have a lower explanatory power for consumers' other-focused anger after a service failure than the attribution model.

Finally, the temporal model of perceived control could better explain repurchase behaviour because it addresses not only the causes of the service failure (something that the attribution model also does), but also the current consequences of the failure for the consumer (present control) and whether the consumer will be able to act to prevent it in the future (Frazier, Keenan, et al., 2011) - cognitions that the attribution model does not address and which may be of great importance when deciding whether to repurchase. Therefore, the following hypothesis was formulated:

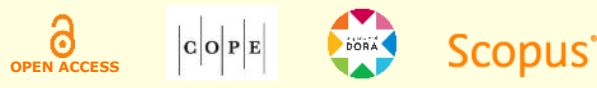


H4: The temporal model of perceived control will have a higher explanatory power for consumers' repurchase behaviour after a service failure than the attribution model.

\section{Empirical Study}

A correlational study compared the explanatory power of the temporal model of perceived control with those of the causal attribution model. The participants were recruited via Mechanical Turk $\left(n=247,62 \%\right.$ women, $\left.M_{\text {age }}=37.51, S D_{\text {age }}=12.08\right)$ and had a consistent approval historic (i.e., they had completed more than 100 HITs and obtained more than $90 \%$ of approval). Mechanical Turk was adopted to recruit participants because of its low-cost, high-quality, reliable data, as well as its increased use and acceptance among marketing researchers (Geuens \& De Pelsmmacker, 2017). The sample size was calculated using the software $G^{*}$ Power. The participants were asked to remember and describe a stressful service episode they had experienced. Afterwards, they completed a questionnaire. Stress was measured on a seven-point scale to make sure that the described situations were stressful $(M=5.81)$. Data was collected in 2014.

\section{Measures}

Table 2 contains the measures used in this study. All variables were measured using seven-point scales.

Table 2

\section{Measures}

\begin{tabular}{|c|c|}
\hline $\begin{array}{l}\text { Name of the variable, Cronbach alpha or } \\
\text { correlation, source }\end{array}$ & Item(s) \\
\hline \multirow{5}{*}{ Past control, $\alpha=.80$, Frazier, Keenan, et al. (2011) } & I could have done something to prevent this event from happening \\
\hline & There is nothing I could have done to prevent this event from occurring $(R)$ \\
\hline & This event happened because of something I did or didn't do \\
\hline & I didn't have any control over the event occurring $(R)$ \\
\hline & I couldn't have prevented it $(R)$ \\
\hline \multirow{8}{*}{$\begin{array}{l}\text { Present control, } \alpha=.79 \text {, Frazier, Keenan, et al. } \\
\text { (2011) }\end{array}$} & There isn't much I can do to help myself feel better about the event (R) \\
\hline & How I deal with this event now is under my control \\
\hline & I don't have much control over my emotional reactions to the event (R) \\
\hline & When I am upset about the event, I can find a way to feel better \\
\hline & I have control over my day-to-day reactions to this event \\
\hline & There isn't much I can do to keep the event from affecting me (R) \\
\hline & I have control over how I think about the event \\
\hline & My reaction to the event is not under my control $(R)$ \\
\hline \multirow{3}{*}{ Future control, $\alpha=.88$, Frazier, Keenan, et al. (2011) } & $\begin{array}{l}\text { I can do things to make sure I will not experience a similar event in the future } \\
\text { There is nothing I can do to prevent a similar event from happening again }(R)\end{array}$ \\
\hline & ) I have no control over whether a similar event happens to me again $(R)$ \\
\hline & $\begin{array}{l}\text { There are things I can do to reduce the risk that a similar event will happen } \\
\text { again }\end{array}$ \\
\hline
\end{tabular}

Continues 


\section{Table 2 (continued)}

\begin{tabular}{ll}
\hline $\begin{array}{l}\text { Name of the variable, Cronbach alpha or } \\
\text { correlation, source }\end{array}$ & Item(s) \\
\hline $\begin{array}{ll}\text { Future likelihood, } \alpha=.93, \text { Frazier, Anders, et al. } \\
(2012)\end{array}$ & $\begin{array}{l}\text { I fully expect something similar to happen to me again } \\
\text { I will not experience something like this again (R) } \\
\text { I'm sure something similar will happen to me again }\end{array}$ \\
& $\begin{array}{l}\text { I don't expect something like this to happen to me again (R) } \\
\text { I don't believe I will ever experience this sort of thing again (R) }\end{array}$ \\
\hline $\begin{array}{l}\text { Causal locus attribution, } \alpha=.78, \text { Chu, Song and } \\
\text { Choi (2013) and McAuley, Duncan and Russell } \\
\text { (1992) }\end{array}$ & $\begin{array}{l}\text { The cause reflected an aspect of yourself (e.g., your choices) / The cause } \\
\text { did not reflect an aspect of yourself }\end{array}$ \\
& $\begin{array}{l}\text { The cause had to do with you / The cause had to do with others } \\
\text { The cause was about you / The cause was about others }\end{array}$ \\
\hline
\end{tabular}

Causal stability attribution, $\alpha=.56$, McAuley et al. The cause was something stable over time / The cause was something (1992) variable over time

The cause was something permanent / The cause was something temporary The cause was something unchangeable / The cause was something changeable

External controllability attribution, $\alpha=.92$, Hess

The cause was not at all controllable by the service provider / The cause was Ganesan and Klein (2007)

\section{definitely controllable by the service provider}

The cause was not at all preventable by the service provider / The cause was definitely preventable by the service provider

The cause was not at all avoidable by the service provider / The cause was definitely avoidable by the service provider

Internal controllability attribution, $\alpha=.89$, Hess et al. The cause was not at all controllable by you / The cause was definitely (2007) controllable by you

The cause was not at all preventable by you / The cause was definitely preventable by you

The cause was not at all avoidable by you / The cause was definitely avoidable by you

Regret, $\alpha=.75$, Yi and Baumgartner (2004) Regretful

Should have known better

Should have made a different choice

\begin{tabular}{ll}
\hline Other-focused anger, Yi and Baumgartner (2004) & Angry with the service provider \\
\hline Self-focused anger, Yi and Baumgartner (2004) & Angry with myself \\
\hline Repurchase behaviour & I kept on doing business with the service provider \\
\hline Stress & Stressed \\
\hline
\end{tabular}

Since controllability may be divided into two types - external versus internal (McAuley, Duncan, \& Russell, 1992) - both types were assessed even though the service literature focuses only on external controllability. The questionnaire was submitted to the qualitative evaluation of two specialists before data collection. In addition, to avoid the occurrence of common method bias, some actions suggested by Podsakoff, MacKenzie, Lee, and Podsakoff (2003) were taken: (a) different response scales were adopted, such as agreement scales and bipolar scales; (b) constructs were measured in different questionnaire pages to create some distance among them; (c) constructs that were expected to influence other constructs were measured at the end of the questionnaire (i.e., perceived control and attributions); (d) participants were informed that their identity would remain anonymous. 


\section{Results}

Table 3 shows how the four components of the temporal model of perceived control correlate with the four causal attribution dimensions measured in this study.

Table 3

Correlations between the temporal model of perceived control and the attribution model

\begin{tabular}{lcccc}
\hline & Past control & Present control & Future control & \multicolumn{2}{c}{ Future likelihood } \\
\hline Locus & $-.47^{* \star *}$ & .08 & $-.21^{\star \star \star}$ & .06 \\
\hline Stability & $-.15^{*}$ & .10 & -.10 & .02 \\
\hline Internal controllability & $.66^{* * *}$ & -.03 & $.28^{* \star *}$ & -.06 \\
\hline External controllability & $-.19^{* *}$ & .10 & .01 & .05 \\
\hline
\end{tabular}

Note. ${ }^{* * *}=$ significant at the 0.001 level; ${ }^{* *}=$ significant at the 0.01 level; ${ }^{*}=$ significant at the 0.05 level.

As presented in Table 3, past control was significant and negatively related to causal locus, stability and external controllability attributions, indicating that the more the participants perceived that they could have prevented the failure, the less they blamed others and thought that the failure was temporary and controllable by the service provider. Past control was significant and positively related to the controllability attribution (i.e., the more the participants perceived that they could have prevented the failure, the more they thought that they could control the failure). Future control was significant and negatively related to the locus attribution and positively related to internal controllability, meaning that the more the participants perceived that they would be able to prevent the failure in the future, the less they blamed others and the more they thought that they could control the failure. Present control and future likelihood were not significantly related to any of the attributions measured in this study.

The four components of the temporal model of perceived control were used as independent variables in multiple regression analyses for each dependent variable. The same procedure was conducted with the four attributions. Tolerance values were above 0.60 , while VIF values were below 2, indicating no sign of collinearity.

The results showed that although the two models could significantly explain variances in regret and self-focused anger $(p<0.001)$, the percentages explained by perceived control were higher than those of attributions (Table 4), supporting H1 and H2. The temporal model of perceived control also had higher explanatory power than the attribution model in terms of the variance in repurchase behaviour (see Table 4). Perceived control explained 11\% $(p<0.001)$ of the repurchase variance, while attributions explained $4 \%$ (n.s.), supporting H4. However, regarding anger towards the service provider, attributions had more predictive power $\left(R^{2}=8 \%, p<0.001\right)$ than perceived control $\left(R^{2}=2 \%\right.$, n.s. $)$, supporting $\mathrm{H} 3$. 
Table 4

Adjusted R2 from linear regressions of regret, anger and repurchase on the temporal model of perceived control and the attribution model

\begin{tabular}{lcccc} 
& \multicolumn{2}{l}{ Dependent variables } & & \\
\cline { 2 - 5 } & Regret & Anger & Anger & Repurchase \\
& & (other-focused) & (self-focused) & $.11^{* * *}$ \\
Perceived control $(\mathrm{k}=4)$ & $.14^{* * *}$ & .02 & $.15^{* * *}$ & .04 \\
Attributions $(\mathrm{k}=4)$ & $.08^{* *}$ & $.08^{* * *}$ & $.11^{* * *}$ & .04 \\
\hline Perceived control + Attributions $(\mathrm{k}=8)$ & $.17^{* * *}$ & $.08^{* *}$ & $.17^{* * *}$ & $.14^{* * *}$ \\
\hline
\end{tabular}

Note. ${ }^{* * *}=$ significant at the 0.001 level; ${ }^{* *}=$ significant at the 0.01 level; $\mathrm{k}=$ number of independent variables

Figure 1 illustrates the variance explained by the temporal model of perceived control and the attribution model. Combining the four components of the temporal model and the four components of the attribution model resulted in a total explained variance that would usually be lower than the mere sum of the variance explained by each separate model. Therefore, to show the additional explanatory power provided by the temporal model when combined with the attribution model, the variance explained by the attribution model alone (using only the four attributions as independent variables) was subtracted from the total explained variance (using the eight components of the two models). The result was the additional explanatory power that the temporal model could provide to the attribution model. Figure 1 clearly shows the added value of combining both models, as far as regret, self-focused anger and repurchase behaviour are concerned.

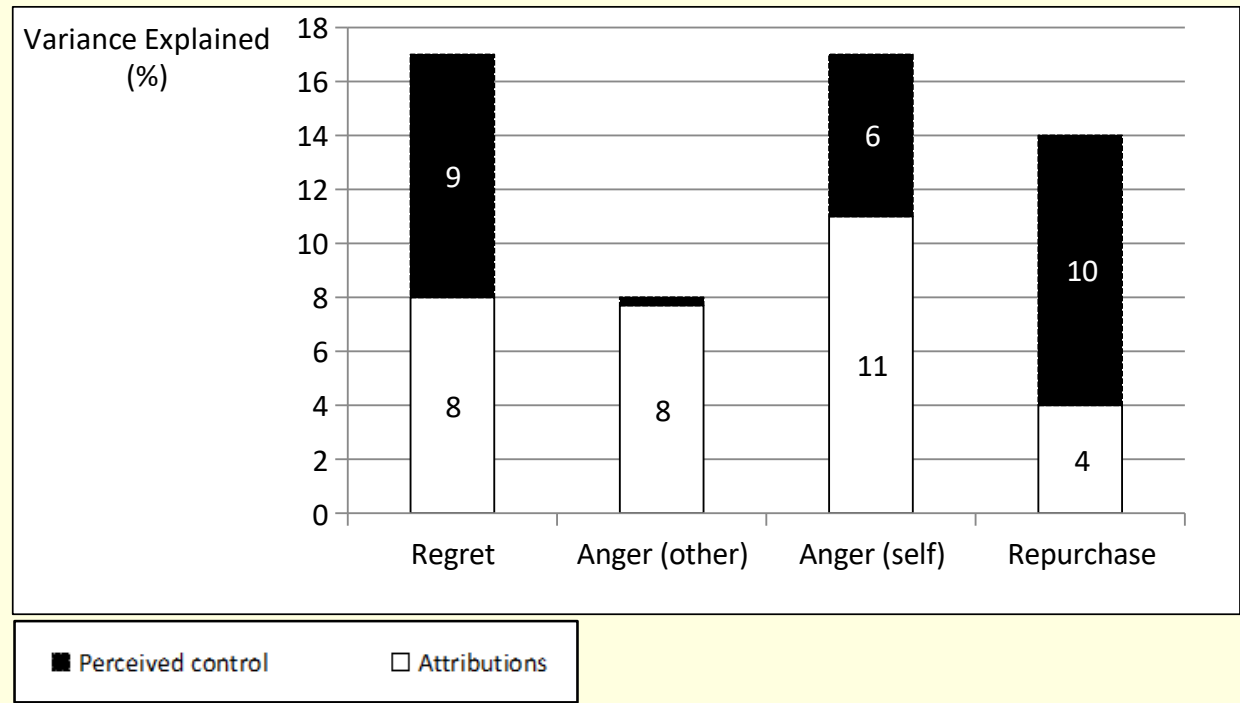

Figure 1. Variances explained by the temporal model of perceived control and the attribution model

Regarding the individual impacts of the four components of the temporal model of perceived control (see Table 5), the explanatory power of past and future control stood out from the rest of the model. Past and future control significantly explained regret, self-focused anger and 
repurchase behaviour. Repurchase behaviour was also explained by future likelihood, while past control was the only component that significantly explained other-focused anger.

Table 5

Standardised coefficients from linear regressions of regret, anger and repurchase on the temporal model of perceived control

\begin{tabular}{lccccc}
\cline { 2 - 4 } & \multicolumn{2}{l}{ Dependent variables } & & \\
\cline { 2 - 5 } & Regret & $\begin{array}{c}\text { Anger } \\
\text { (other-focused) }\end{array}$ & $\begin{array}{c}\text { Anger } \\
\text { (self-focused) }\end{array}$ & Repurchase \\
Perceived past control & $.17^{* *}$ & $-.13^{*}$ & $.33^{* *}$ & $.14^{* *}$ \\
Perceived present control & -.10 & -.04 & -.04 & .05 \\
Perceived future control & $.28^{* * *}$ & .04 & $.12^{*}$ & $-.29^{* * *}$ \\
\hline Perceived future likelihood & .02 & .04 & -.05 & $.12^{*}$ \\
\hline
\end{tabular}

Note. ${ }^{* * *}=$ significant at the 0.001 level; ${ }^{* *}=$ significant at the 0.05 level; ${ }^{*}=$ significant at the 0.10 level.

\section{Discussion}

This study results suggest that the temporal model of perceived control is superior to the wellknown causal attribution model in terms of explaining regret, self-focused anger and repurchase behaviour after a stressful service episode. This finding indicates that this temporal model developed by Frazier, Anders, et al. (2012) and Frazier, Keenan, et al. (2011) to explain stressful life situations - could contribute to service research. Moreover, different components of the temporal model (i.e., perceived past control, perceived future control and perceived future likelihood) are significantly related to at least one of the reactions measured in this study, showing how important the temporal dimension is. For instance, if only past control is examined when trying to figure out how consumers would react to a service failure, the significant effects of future control and future likelihood would be missed. Although the current study shows no significant effect of present control on the four dependent variables, present control has been shown to be a better predictor of psychological distress than past or future perceived control (Misono et al., 2016), which means it is an important component of the temporal model and can be a good predictor of other consumer reactions. The results of the current study as well as previous studies showing the significant effects of the temporal model and each one of its components on psychological distress and well-being (Frazier, Anders, et al., 2012; Frazier, Keenan, et al., 2011; Misono et al., 2016; Sirois et al., 2006) indicate that the model is definitely worthy of consideration and further investigation.

The fact that the attribution model explains the variance in other-focused anger better than the temporal model should be due to the external focus of this emotion. Since the temporal model focuses on the individual's role rather than on the service provider's role, it may be a strong predictor of self-focused emotions (e.g., regret and self-focused anger), with lower explanatory power for other-focused emotions (e.g., other-focused anger). An individual only gets angry with someone when the former is convinced that the latter deliberately caused harm or was negligent

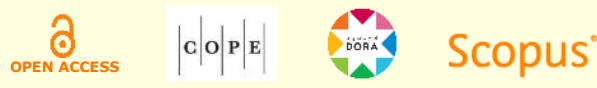


(Joireman et al., 2013; Weiner, 2000). This type of cognition is not assessed through the temporal model, but can be evaluated with external controllability attributions.

The comparison among the two models investigated in this study does not imply that one of them has to be chosen to explain service failures. In fact, the temporal model of perceived control could be used together with the attribution model. Perhaps one of the best contributions of the temporal model, combined with the attribution model, is providing the opportunity to investigate the individual's role when he or she is not the cause of a stressful situation (external causal attribution). According to the attribution model, if the blame is not attributable to an actor (e.g., the consumer), the actor cannot control it. Weiner states:

However, it could be argued that all external causes are uncontrollable by the actor. Thus, locus and control are not orthogonal dimensions of causality although they are distinguishable. In addition, however, external causes may be controllable or uncontrollable by others (2014, p. 356).

This idea that the actor cannot control an external cause is overcome by using the temporal model of perceived control, combined with the attribution model. In other words, even when the service provider does something wrong, individuals may ruminate about whether they could have done something differently. When encountering a failed service, people may think, It was not my fault, but I could have prevented it. The attribution model in itself cannot address this kind of situation although it may lead to different consumer reactions compared with a situation in which consumers think that there was nothing that they could have done. For instance, in the present study, the participants reported service failures where they scored high in perceived past control and external causal attribution. Table 6 cites some examples.

Table 6 shows that sometimes, consumers think that they could have prevented a service failure even when they did not cause the failure. Researchers will be able to understand and predict this type of situation when using the temporal model of perceived control with the attribution model. It makes the temporal model a handy resource to analyse failure situations differently than attributions do. Moreover, perceived control determines people's responses to life events (Burger, 1989), affecting emotions and behaviours regardless of actual control conditions (Geer, Davison, \& Gatchel, 1970; Skinner, 1996). For instance, perceived control decreases distress in face of numerous medical conditions (e.g., cardiac problems and cancer), "indicating that although the situation itself may or may not be controllable, the patient's response to the situation plays an important role in outcomes" (Misono et al., 2016, p. 173). Besides the importance of perceived control in many life situations that do not include consuming goods or services, perceived control is also important for this latter context too, as it leads to more pleasurable purchase and service experiences and, consequently, to approach behaviour (Hui \& Bateson, 1991; Rompay et al., 2008). Therefore, it is important to consider consumers' perceived control (and its temporal dimension) in service failures situations. 
Table 6

Service failures ranked high in perceived past control and external causal locus attribution

\begin{tabular}{lcc}
\hline Service failure & $\begin{array}{c}\text { Causal locus } \\
\text { attribution* }\end{array}$ & $\begin{array}{c}\text { Perceived past } \\
\text { control }\end{array}$ \\
\hline 1) My internet had not been working as it should. My service provider sent 3 & 7.0 \\
technicians out. The first texted on his cell phone for 5 minutes them left and said \\
he would call someone for outside wiring. The second checked my inside wiring \\
and said he would call someone for outside wiring and never did. The third \\
replaced my modem and left. Then, I had a \$ 400 internet bill for technician \\
services. \\
2) I went to this store and I really felt bad. I felt that I wasn't wanted as a customer \\
and I felt that I was being ignored. People walked past me and didn't even ask if I \\
needed help. I know I had a look of not being able to find what I want. I wanted to \\
get out of that store really quick. I thought it was a good chain. It may have been \\
just that store but I haven't been to that chain again yet. It made me think badly of \\
them. \\
3) I was at a deli next in line to get meat and an older lady came up and cut in front \\
of me. The girl behind the counter knew I was next, but the old lady was so pushy \\
she helped her anyway. I wasn't in a hurry so it wasn't that big of a deal, but it was \\
still annoying that I had to wait for the lady to get her food first, and I know the girl \\
working the counter knew I was next. \\
4) I can certainly think of a most recent stressful time at the supermarket. I go \\
there because it is very close to my house but sorry I went there the other night. \\
First it starts with the deli - 4 or 5 people behind the counter - 5 to 6 waiting on line \\
and NO one bothers to help us. I've reported this to the office. Then it gets more \\
stressful when people are practically running into you with their carts and then \\
when it's time to check out the lines DO not move!!! It's enough to have a panic \\
attack over and believe me it's happened. \\
\hline
\end{tabular}

Note. ${ }^{*}$ Higher numbers represent more external attributions. All scales ranging from 1 to 7.

\section{Conclusion}

This paper represents an initial effort to incorporate the temporal model of perceived control in studies about service failure. The temporal dimension of perceived control has not been investigated in service research - neither in the model developed by Frazier, Anders, et al. (2012) and Frazier, Keenan, et al. (2011) nor in other temporal models. The temporal model offers significant results on its own, but can also be combined with the causal attribution model to increase the predictive power for consumers' emotional and behavioural responses.

The current results have both theoretical and managerial implications. From a theoretical perspective, the temporal model of perceived control can be used in service failure research to gain a better understanding of consumers' emotional and behavioural reactions. It broadens the scope of service research as it enables examining the consumers' role during and after service failures, which has been overlooked in the area.

From a managerial perspective, consumer-perceived control - which service companies can manage - helps predict consumer reactions to a service failure. If they wish, service companies could increase consumer-perceived control by providing antecedents of control (i.e., information, predictability and choice) to consumers (Skinner, 1996). In other words, service providers could increase consumer-perceived control by providing relevant information about the service process

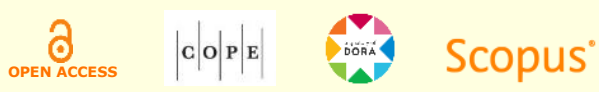


(e.g., the steps and the total length of the process), telling consumers what to expect from the service outcome (e.g., how the service outcome will look) and giving them some options (e.g., letting them choose some of the service features). Service providers could also increase consumerperceived control by encouraging consumer participation in service production/delivery (Chan, Yim, \& Lam, 2010; Pacheco et al., 2013). Knowing the different effects of perceived control on consumer reactions may help service companies decide the most suitable occasions to raise consumer-perceived control.

As the first to use the temporal model of perceived control in service failure research, this paper has limitations concerning the scope of its investigation. Space constraints have not made it possible to investigate the broad range of consumer emotions and behaviours that could be affected by the model (e.g., guilt, disappointment, shame). Each emotion leads to particular ways of coping with it, as well as specific behaviours. For instance, regretful consumers have different behavioural reactions compared with disappointed ones (Zeelenberg \& Pieters, 2004). For this reason, it is relevant to understand whether and how the temporal model of perceived control could influence other emotions. Future studies could scrutinise the effects of each component of the temporal model (i.e., past, present and future control and future likelihood) on different emotions.

Moreover, interactive effects that could exist among the components of the temporal model have not been investigated. This aspect may be addressed in future research because different types of control may interact, reducing or enhancing each other's effects (Guo, Lotz, Tang, \& Gruen, 2015). Because perceived control and causal attributions are related to each other (Hui \& Toffolli, 2002), potential interactive effects between the temporal model of perceived control and the attribution model could also be investigated in future research. For instance, perceived future control may affect causal stability attribution; the more someone thinks that one can prevent an event's recurrence, the more one thinks that the cause is temporary. On the other hand, future control and stability attribution could be totally unrelated; their correlation in the present study is non-significant $(p>0.10)$. In this case, it would be interesting to investigate the outcome when consumers think that the cause of a failure is permanent (stable and therefore likely to recur), while believing that they could prevent the failure from happening again (future control). What would affect consumers' repurchase intention more - the fact that whatever caused the service failure has not been fixed yet or the fact that they would be able to prevent its recurrence? If stability matters more, repurchase intention should be negatively affected (decreased repurchase intention). If perceived future control is more important than stability, consumers who think that they can prevent a failure can continue doing business with the same service provider because they know what to do to prevent the failure.

The temporal model of perceived control was used in this study in exactly the same way as Frazier, Anders, et al. (2012) did (i.e., the same four components and 22 items) to explain emotional and behavioural reactions to various stressful life events. To apply it in a more specific context, such as service failure, researchers can adapt the model by using different components and items relevant to the context. For instance, a second type of perceived present control that could be investigated in the context of service failure is whether consumers have any control over the

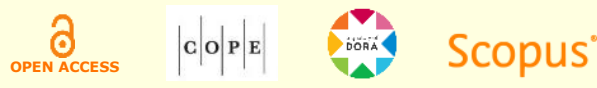


current failure by acting to correct or mitigate the consequences of the failure rather than simply trying to control their thoughts and emotions about it. For example, when a service employee is rude, consumers can perform certain actions during this rude treatment (e.g., ask to talk to another employee, tell the rude person to calm down, leave the place/store) or afterwards (e.g., complain to the manager, complain to the rude person), which neither involve controlling their emotions and thoughts nor preventing the recurrence of the event.

\section{References}

Bolkan, S., Goodboy, A. K., \& Daly, J. A. (2010). Consumer satisfaction and repatronage intentions following a business failure: The importance of perceived control with an organizational complaint. Communication Reports, 23(1), 14-25. https://doi.org/10.1080/08934211003598767

Bonifield, C., \& Cole, C. (2007). Affective to service failure: Anger, regret, and retaliatory versus conciliatory responses. Marketing Letters, 18(1-2), 85-99. https://doi.org/10.1007/s11002-006-9006-6

Bougie, R., Pieters, R., \& Zeelenberg, M. (2003). Angry customers don' t come back, they get back: The experience and behavioral implications of anger and dissatisfaction in services. Journal of the Academy of Marketing Science, 31(4), 377-393. https://doi.org/10.1177/0092070303254412

Burger, J. M. (1989). Negative reactions to increases in perceived personal control. Journal of Personality and Social Psychology, 56(2), 246-256. https://doi.org/10.1037/0022-3514.56.2.246

Chan, K. W., Yim, C. K. (Bennett), \& Lam, S. S. K. (2010). Is customer participation in value creation a doubleedged sword? Evidence from professional financial. Journal of Marketing, 74(3), 48-64. https://doi.org/http://dx.doi.org/10.1509/jmkg.74.3.48

Chang, C.-C. (2008). Choice, perceived control, and customer satisfaction: The psychology of online service recovery. Cyberpsychology E Behavior, 11(3), 321-328. https://doi.org/10.1089/cpb.2007.0059

Chu, W., Song, M. R., \& Choi, B. (2013). Post-purchase disadvantages of a less preferred brand and how they can be overcome: An examination of regret and attribution. Journal of Applied Social Psychology, 43(4), 887-898. https://doi.org/10.1111/jasp.12014

Dabholkar, P. A., \& Sheng, X. (2009). The role of perceived control and gender in consumer reactions to download delays. Journal of Business Research, 62(7), 756-760. https://doi.org/10.1016/j.jbusres.2008.06.001

Dellaert, B. G. C., \& Dabholkar, P. A. (2009). Increasing the attractiveness of mass customization: The role of complementary on-line services and range of options. International Journal of Electronic Commerce, 13(3), 43-70. https://doi.org/10.2753/JEC1086-4415130302

Dunn, L., \& Dahl, D. W. (2012). Self-threat and product failure: How internal attributions of blame affect consumer complaining behavior. Journal of Marketing Research, 49(5), 670-681. https://doi.org/10.1509/jmr.11.0169

Elwalda, A., Lü, K., \& Ali, M. (2016). Perceived derived attributes of online customer reviews. Computers in Human Behavior, 56, 306-319. http://dx.doi.org/10.1016/j.chb.2015.11.051

Folkes, V. S. (1984). Consumer reactions to product failure: An attributional approach. Journal of Consumer Research, 10(4), 398-409. https://doi.org/10.1086/208978

Folkes, V. S., Koletsky, S., \& Graham, J. L. (1987). A field study of causal inferences and consumer reaction: The view from the airport. Journal of Consumer Research, 13(4), 534-539. https://doi.org/10.1086/209086

Frazier, P., Anders, S., Shallcross, S., Keenan, N., Perera, S., Howard, K., \& Hintz, S. (2012). Further development of the temporal model of control. Journal of Counseling Psychology, 59(4), 623-630. https://doi.org/10.1037/a0029702

Frazier, P., Berman, M., \& Steward, J. (2001). Perceived control and posttraumatic stress: A temporal model. Applied and Preventive Psychology, 10(3), 207-223. https://doi.org/10.1016/S0962-1849(01)80015-9

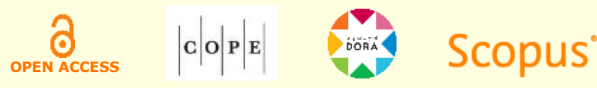


Frazier, P., Keenan, N., Anders, S., Perera, S., Shallcross, S., \& Hintz, S. (2011). Perceived past, present, and future control and adjustment to stressful life events. Journal of Personality and Social Psychology, 100(4), 749-765. https://doi.org/10.1037/a0022405

Frazier, P., Meredith, L., Greer, C., Paulsen, J. A., Howard, K., Dietz, L. R., \& Qin, K. (2014). Randomized controlled trial evaluating the effectiveness of a web-based stress management program among community college students. Anxiety, Stress, E Coping, 28(5), 576-586. https://doi.org/10.1080/10615806.2014.987666

Geer, J. H., Davison, G. C., \& Gatchel, R. I. (1970). Reduction of stress in humans through nonveridical perceived control of aversive stimulation. Journal of Personality and Social Psychology, 16(4), 731-738. https://doi.org/10.1037/h0030014

Geuens, M., \& De Pelsmacker, P. (2017). Planning and conducting experimental advertising research and questionnaire design. Journal of Advertising, 46(1), 83-100. https://doi.org/10.1080/00913367.2016.1225233

Grégoire, Y., Laufer, D., \& Tripp, T. M. (2010). A comprehensive model of customer direct and indirect revenge: Understanding the effects of perceived greed and customer power. Journal of the Academy of Marketing Science, 38(6), 738-758. https://doi.org/10.1007/s11747-009-0186-5

Guo, L., Lotz, S. L., Tang, C., \& Gruen, T. W. (2015). The role of perceived control in customer value cocreation and service recovery evaluation. Journal of Service Research, 19(1), 1-18. https://doi.org/10.1177/1094670515597213

Harris, K. E., Mohr, L. A., \& Bernhardt, K. L. (2006). Online service failure, consumer attributions and expectations. Journal of Services Marketing, 20(7), 453-458. https://doi.org/10.1108/08876040610704883

Hess, R. L., Jr., Ganesan, S., \& Klein, N. M. (2003). Service failure and recovery: The impact of relationship factors on customer satisfaction. Journal of the Academy of Marketing Science, 31(2), 127-145. http://doi.org/10.1177/0092070302250898

Hess, R. L., Jr., Ganesan, S., \& Klein, N. M. (2007). Interactional service failures in a pseudorelationship: The role of organizational attributions. Journal of Retailing, 83(1), 79-95. https://doi.org/10.1016/j.jretai.2006.10.010

Huang, W.-H., Lin, Y.C., \& Wen, Y.-C. (2010). Attributions and outcomes of customer misbehavior. Journal of Business and Psychology, 25(1), 151-161. https://doi.org/10.1007/s10869-009-9137-x

Hui, M. K., \& Bateson, J. E. G. (1991). Perceived control and the effects of crowding and consumer choice on the service experience. Journal of Consumer Research, 18(2), 174-184. https://doi.org/10.1086/209250

Hui, M. K., \& Toffoli, R. (2002). Perceived control and consumer attribution for the service encounter. Journal of Applied Social Psychology, 32(9), 1825-1844. https://doi.org/10.1111/j.1559-1816.2002.tb00261.x

Iglesias, V. (2009). The attribution of service failures: Effects on consumer satisfaction. The Service Industries Journal, 29(2), 127-141. https://doi.org/10.1080/02642060802293088

Joireman, J., Grégoire, Y., Devezer, B., \& Tripp, T. M. (2013). When do customers offer firms a "second chance" following a double deviation? The impact of inferred firm motives on customer revenge and reconciliation. Journal of Retailing, 89(3), 315-337. https://doi.org/10.1016/j.jretai.2013.03.002

Kalamas, M., Laroche, M., \& Makdessian, L. (2008). Reaching the boiling point: Consumers' negative affective reactions to firm-attributed service failures. Journal of Business Research, 61(8), 813-824. https://doi.org/10.1016/j.jbusres.2007.09.008

Kang, H., Hahn, M., Fortin, D. R., Hyun, Y. J., \& Eom, Y. (2006). Effects of perceived behavioral control on the consumer usage intention of e-coupons. Psychology $\mathbb{E}$ Marketing, 23(10), 841-864. https://doi.org/10.1002/mar.20136

Kumar, P. K., \& Anand, B. (2015). The impact of innovation, green advertising and perceived behavioral control on green consumer behavior. Scholars Journal of Economics, Business and Management, 2(2A), 182-190. Retrieved from https://saspjournals.com/wp-content/uploads/2015/02/SJEBM-22A182-190.pdf

L. (2017, August 6). Quest diagnostics consumer reviews and complaints [Online forum comment]. Retrieved from https://www.consumeraffairs.com/health/quest_diagnostics.html?page=5

Li, Y., Xu, Z., \& Xu, F. (2018). Perceived control and purchase intention in online shopping: The mediating role of self-efficacy. Social Behavior and Personality, 46(1), 99-106. https://doi.org/10.2224/sbp.6377

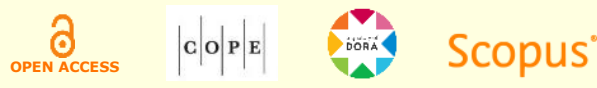


Lunardo, R., \& Mbengue, A. (2009). Perceived control and shopping behavior: The moderating role of the level of utilitarian motivational orientation. Joumal of Retailing and Consumer Services, 16(6), 434-441. https://doi.org/10.1016/j.jretconser.2009.06.004

McAuley, E., Duncan, T. E., \& Russell, D. W. (1992). Measuring causal attributions: The revised causal dimension scale (CDSII). Personality and Social Psychology Bulletin, 18(5), 566-573. https://doi.org/10.1177/0146167292185006

Misono, S., Meredith, L., Peterson, C. B., \& Frazier, P. A. (2016). New perspective on psychosocial distress in patients with dysphonia: The moderating role of perceived control. Journal of Voice, 30(2), 172-176. https://doi.org/10.1016/j.jvoice.2015.02.002

Namasivayam, K., \& Mount, D. J. (2006). A field investigation of the mediating effects of perceived fairness on the relationship between perceived control and consumer satisfaction. Joumal of Hospitality $\mathcal{E}$ Tourism Research, 30(4), 494-506. https://doi.org/10.1177/1096348006289970

Namasivayam, K., \& Guchait, P. (2013). The role of contingent self-esteem and trust in consumer satisfaction: Examining perceived control and fairness as predictors. International Journal of Hospitality Management, 33, 184. 195. https://doi.org/10.1016/j.ijhm.2012.08.002

Noone, B. M., Wirtz, J., \& Kimes, S. E. (2012). The effect of perceived control on consumer responses to service encounter pace: A revenue management perspective. Cornell Hospitality Quarterly, 53(4), 295-307. https://doi.org/10.1177/1938965512460343

P. (2017, July 25). Quest diagnostics consumer reviews and complaints [Online forum comment]. Retrieved from https://www.consumeraffairs.com/health/quest_diagnostics.html?page=5

Pacheco, N. A., Lunardo, R., \& Santos, C. P. dos. (2013). A perceived-control based model to understanding the effects of co-production on satisfaction. BAR - Brazilian Administration Review, 10(2), 219-238. https://doi.org/10.1590/S1807-76922013000200007

Podsakoff, P. M., MacKenzie, S. B., Lee, J.-Y., \& Podsakoff, N. P. (2003). Common method biases in behavioral research: A critical review of the literature and recommended remedies. The Journal of Applied Psychology, 88(5), 879-903. https://doi.org/10.1037/0021-9010.88.5.879

Rompay, T. J. L. van, Galetzka, M., Pruyn, A. T. H., \& Garcia, J. M. (2008). Human and spatial dimensions of retail density: Revisiting the role of perceived control. Psychology $\mathscr{E}$ Marketing, 25(4), 319-335. https://doi.org/10.1002/mar.20211

Saffrey, C., Summerville, A., \& Roese, N. J. (2008). Praise for regret: People value regret above other negative emotions. Motivation and Emotion, 32(1), 46-54. https://doi.org/10.1007/s11031-008-9082-4

Shimanoff, S. B. (1984). Commonly named emotions in everyday conversations. Perceptual and Motor Skills, 58(2), 514-514. https://doi.org/10.2466/pms.1984.58.2.514

Sirois, F. M., Davis, C. G., \& Morgan, M. S. (2006). "Learning to live with what you can't rise above”: Control beliefs, symptom control, and adjustment to tinnitus. Health Psychology, 25(1), 119-123. https://doi.org/10.1037/0278-6133.25.1.119

Skinner, E. A. (1996). A guide to constructs of control. Journal of Personality and Social Psychology, 71(3), 549-570. http://dx.doi.org/10.1037/0022-3514.71.3.549

Smyth, J. M., Wonderlich, S. A., Heron, K. E., Sliwinski, M. J., Crosby, R. D., Mitchell, J. E., \& Engel, S. G. (2007). Daily and momentary mood and stress are associated with binge eating and vomiting in bulimia nervosa patients in the natural environment. Journal of Consulting and Clinical Psychology, 75(4), 629-638. https://doi.org/10.1037/0022-006X.75.4.629

Strizhakova, Y., Tsarenko, Y., \& Ruth, J. A. (2012). "I'm mad and I can't get that service failure off my mind”: Coping and rumination as mediators of anger effects on customer intentions. Journal of Service Research, 15(4), 414-429. https://doi.org/10.1177/1094670512443999

Tangney, J. P., Hill-Barlow, D., Wagner, P. E., Marschall, D. E., Borenstein, J. K., Sanftner, J., Mohr, T., \& Gramzow, R. (1996). Assessing individual differences in constructive versus destructive responses to anger across the lifespan. Journal of Personality and Social Psychology, 70(4), 780-796. https://doi.org/10.1037//0022-3514.70.4.780

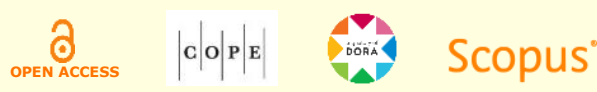


Taylor, S. (1994). Waiting for service: The relationship between delays and evaluations of service. Journal of Marketing, 58(2), 56-69. https://doi.org/10.2307/1252269

Uhrich, S. (2011). Explaining non-linear customer density effects on shoppers' emotions and behavioral intentions in a retail context: The mediating role of perceived control. Journal of Retailing and Consumer Services, 18(5), 405413. https://doi.org/10.1016/j.jretconser.2011.06.002

Wallston, K. A., Wallston, B. S., Smith, S., \& Dobbins, C. J. (1987). Perceived control and health. Current Psychology, 6(1), 5-25. https://doi.org/10.1007/BF02686633

Weiner, B. (1985). An attributional theory of achievement motivation and emotion. Psychological Review, 92(4), 548 573. http://dx.doi.org/10.1037/0033-295X.92.4.548

Weiner, B. (2000). Attributional thoughts about consumer behavior. Journal of Consumer Research, 27(3), 382-387. https://doi.org/10.1086/317592

Weiner, B. (2010). The development of an attribution-based theory of motivation: A history of ideas. Educational Psychologist, 45(1), 28-36. https://doi.org/10.1080/00461520903433596

Weiner, B. (2014). The attribution approach to emotion and motivation: History, hypotheses, home runs, headaches/heartaches. Emotion Review, 6(4), 353-361. https://doi.org/10.1177/1754073914534502er.sagepub.com

Wirtz, J., \& Mattila, A. S. (2004). Consumer responses to compensation, speed of recovery and apology after a service failure. International Journal of Service Industry Management, 15(2), 150-166. https://doi.org/10.1108/09564230410532484

Yi, S., \& Baumgartner, H. (2004). Coping with negative emotions in purchase-related situations. Journal of Consumer Psychology, 14(3), 303-317. https://doi.org/10.1207/s15327663jcp1403_11

Zeelenberg, M., \& Pieters, R. (2004). Beyond valence in customer dissatisfaction. Journal of Business Research, 57(4), 445-455. https://doi.org/10.1016/S0148-2963(02)00278-3

Zeelenberg, M., \& Pieters, R. (2007). A theory of regret regulation 1.0. Journal of Consumer Psychology, 17(1), 3-18. https://doi.org/10.1207/s15327663jcp1701_3

\section{Author contributions}

This manuscript is the main outcome of the 1st author's Ph.D. dissertation, which was supervised by the 2 nd and 3rd authors. The three authors actively participated in the elaboration of the literature review, methodological procedures, statistical analyses, discussion of results, and final revision.

\section{Authors}

\section{Natalia Araujo Pacheco}

IPAM Lisboa

Estrada da Correia, 53, 1500-210, Lisboa, Portugal

natalia.a.pacheco@gmail.com

(iD) http://orcid.org/0000-0001-5607-9326

\section{Cristiane Pizzutti}

Universidade Federal do Rio Grande do Sul, Escola de Administração

Rua Washington Luis, 855, 90010-460, Porto Alegre, RS, Brazil

cristiane.pizzutti@ufrgs.br

(iD) https://orcid.org/0000-0003-4188-5418

\section{Maggie Geuens}

Universiteit Gent, Faculteit Economie en Bedrijfskunde

Tweekerkenstraat 2, 9000, Gent, Belgium

maggie.geuens@ugent.be

(iD) https://orcid.org/0000-0001-6535-7260

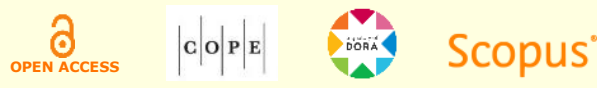

